\title{
The Features of Manifestation of Students' Subjectness
}

\author{
Aksana N. Yashkova ${ }^{1} \&$ Aidar M. Kalimullin ${ }^{2}$ \\ ${ }^{1}$ Mordovian State Pedagogical Institute, Saransk, Russia \\ ${ }^{2}$ Kazan (Volga region) Federal University, Kazan, Russia \\ Correspondence: Aksana N. Yashkova, Mordovian State Pedagogical Institute, Studencheskaya Street 11, \\ Saransk, 430007, Russia. E-mail: yashkovaan@mail.ru
}

Received: January 19, 2014 Accepted: February 22, 2015 Online Published: March 30, 2015

doi:10.5539/res.v7n5p211 URL: http://dx.doi.org/10.5539/res.v7n5p211

\begin{abstract}
The article is of current importance in the field of pedagogics and psychology of higher education as it reveals psychological prerequisites for formation of a specialist and his/her productive self-realization as of the subject of activity. The purpose of the paper is to study the features of manifestation of students' subjectness which ensures success in mastering professional education. The author considers the conception of this phenomenon as a psychological formation and discloses its manifestation through a set of subject actions of a student. The main subject actions include self-actualization and self-control, which provide the quality of the student subjectness manifestation in the process of mastering professional competence. The materials of the present paper can be useful for high school lecturers and students seeking for self-improvement and self-development.
\end{abstract}

Keywords: subject, subjectness, subject actions, student, professional competence, professional education

\section{Introduction}

The considered problem of manifestation of student subjectness is relevant of today as it is becoming important for a person to use the ability to transform the inner and outer world. This makes it less difficult to adapt to the environment of one's vital activity, to find one's place and to realize oneself. This is particularly necessary in high school conditions of mastering professional competence of a specialist. This problem is discussed in the works of Aksyonova (1999), Vardanyan (1998), Volkova (1992), Eneeva (1999), etc.

Slastenin's school (2000) has developed a regulation according to which professional and personal development is based on the principle that implies self-development and the determining ability of a person to turn their own vital activity into the subject of practical transformation leading to creative self-actualization. In high school a person comes up against various situations: new requirements and forms of receiving education, conditions of educational activity implementation, and yet they change their day regimen, the usual behavioral actions and views. The student occasionally faces them in the course of learning process and during exams. At the same time, he is compelled to mobilize himself and to find the ways of self-realization. As a result, on the one hand, these situations require stability (steadiness) of expression of subject manifestations in relation to receiving professional education, and, on the other hand, they demand constant transformation of the inner and outer world for their preservation and improvement in the process of high school training. Such static and dynamic character of a student as of a subject mastering professional competence is provided by his/her subjectness.

\section{Literature Review}

The modern conception of subjectness is based on the statements developed in national psychology of the XX century, which cover the nature of the subject as a carrier of subject-practical activity directed at the object (Ananyev, 1968; Brushlinsky, 1994; Rubinstein, 1989, etc.); subjectness as a property of a person capable of transforming the world and themselves in it at an individ, personal, subject and individual levels of reflection of the inner world (Rubinstein, 1989; Petrovsky, 1990; Petrovsky, 1993; Slobodchikov, 1994, etc.).

The analysis carried out has demonstrated that the scientific idea of subjectness is ambiguous. Scientists define this phenomenon as:

- A subject position which reflects a way of self-realization, self-assertion, self-development of a person (Aksenova, 1999; Slastenin, 2000, etc.); 
- A property of an individual, mental formation, which is based on the relation of man to himself as the doer of an action (Volkova, 1992; Myasishchev, 1995, etc.);

- The highest form of behavior regulation manifested through activity, initiative and awareness of the person's relation to the world, themselves and the carried-out activity (Zimnyaya, 1997);

- A central formation of human subjectness (Slobodchikov, 1994);

- A characteristic of subject activity occurring in his/her activity and behavior (Osnitsky, 1996; Slastenin, 2000, etc.).

We consider the phenomenon of subjectness of a student as a professionally significant mental formation which is reflected in the ability of a student to dispose of resources of their own inner world in the course of mastering professional competence by applying a set of subject actions in educational activity and professional practice.

A theoretical analysis has found (Rubinstein, 1989; Zimnyaya, 1997; Eneeva, 1999, etc.) that subjectness in activity is characterized by the following features:

- Active attitude towards oneself and surrounding reality;

- Transforming attitude towards oneself and one's activity;

- Interactivity, awareness and indepent realization of transformations.

In addition, the doer of an action implements subjectness by means of subject actions (Davydov, 1996; Zimnyaya, 1997; Petrovsky, 1990; Rubinstein, 1989; Eneeva, 1999, etc.), which are the external form of its expression.

In accordance with the conception developed during the present research, subject action is a complete act of behavior by means of which self-realization and self-transformation are performed. This term also implies the implementation and transformation of the process and the result of activity performed by the subject (Yashkova, 2003). The availability of these actions provides the student with the tools for development of subjectness in mastering professional competence (Yashkova, 2012).

We distinguish self-actualization and self-control among the main subject actions.

In the context of the study, self-actualization is defined as an action providing the completeness of self-expression and the demand of manifestation of subjectness in educational activity and professional practice of a student. This action precedes subject self-expression of a future specialist in the process of mastering their professional competence. In this regard self-actualization is considered and actually is the main subject action.

In the present article, we reveal the conception of self-control through the action providing the student with an opportunity to accompany the process of self-realization from the moment of setting an objective to its realization into the expected result through putting it forward independently, through search and implementation of solutions and means to achieve it, through analysis and evaluation of the results obtained, as well as setting new purposes.

\section{Materials and methods}

To study the peculiarities of manifestation of the students' subjectness in the process of mastering professional competence, an empirical research was carried out.

This involves solving the following objectives:

1) To disclose the conception of subjectness of a specialist at a high school stage of its development.

2) To study empirically the level of development of such subject actions as self-actualization and self-control.

3) To single out the indicators for assessing manifestations of students' subjectness in the process of receiving higher education.

In the present study, the principles of unity of consciousness and activity, the development of mentality in activity, a system approach to the study of mental manifestations were considered. The fundamental statements mentioned below are significantly relevant in terms of concept. They cover:

- The nature of the subject as a carrier of subject-practical activities, directing its activity at the object (Ananyev, 1968; Brushlinsky, 1994; Rubinstein, 1989, etc.);

- Subjectness as the ability of a person to carry out transformations of the outer and inner world (Petrovsky, 1990; Petrovsky, 1993; Slobodchikov, 1994, etc.); 
- Mechanisms and factors of development of subject manifestations of the specialist in the course of professional formation (Aksenova, 1999; Vardanyan, 1998; Volkova, 1992; Kuzmina, 1989; Markova, 1993; Slastenin, 2000, etc.).

The study was conducted with students of one of Russian pedagogical institutions of higher education. A total of about 200 senior students participated in it. In the process of implementation of empirical research, the following diagnostic methods were used:

-"Self-actualization test", which is based on the conception of a self-actualizing individual as described by Maslow (2009) and is aimed at identifying the features of manifestation and the level of self-actualization as the highest human need;

- Test "The ability to control oneself", designed for studying the level of development of components of the ability of the human self-control in different situations.

\section{Results}

Diagnostic results obtained by means of "Self-actualization test" (SAT) demonstrated the presence of low self-actualization of value orientations (VO), their self-mobilization and self-realization, flexibility of behavior and thinking (F), accepting oneself the way they are (SA), in communication (Co), in education process (PP) and in creative work $(\mathrm{Cr})$, since the indicators of self-actualization are located outside its borders, and only self-actualization of self-respect ( $\mathrm{Sr}$ ) is implemented within the normal range.

As a result, according to SAT three groups of students were distinguished.

The first group included students with intensive self-actualization (11.8\%). The representatives of this group consciously assessed, fully and completely, the implementation of self-actualization as a subject action in relation to themselves (in self-esteem, self-acceptance) as well as in relation to external reality (in realization of value orientations, communication, cognitive activity, correction, creative work, flexibility of behavior and thinking). They also demonstrated uniformity of manifestation of self-actualization towards the inner and outer world. It was well observed because, as reflected on individual charts, the values of subject actions of different scales located at an optimal level of self-actualization implementation.

The second group of participants characterizes the level of partial realization of self-actualization (72.9\%). It was made up by the majority of students. They showed an incomplete picture of application of subject action in relation to both themselves and changes of the outer world of their vital activity. These students demonstrated very different levels of manifestation of self-actualization of value orientations, flexibility of behavior and thinking, correction, in communication, in educational process. In this group, interesting results on actualization of self-acceptance and self-esteem are observed. Many students actualizing respect to themselves don't actualize self-acceptance, or vice versa.

The third group of participants is characterized by incomplete self-actualization of potentialities $(15.3 \%)$. It comprises students who have the lowest assessment of self-actualization on scales, or excessive, exorbitant optimum level of expression of subject action. These undergraduates demonstrate fragmentation in manifestation of self-actualization of their subject potentialities in relation to themselves as to the subject and to external reality.

The results of the test "The ability to control oneself" allowed to define the availability of the mid-level of self-assessment of ability to carry out such subject actions as the analysis of contradictions or orientation in situations (An), goal-setting $(\mathrm{G})$, the development of quality assessment criteria (Qa), decision-making (Dm), self-control (Sc). Below average level is found on the results of self-esteem of subjectness to perform forecasting $(\mathrm{F})$, planning $(\mathrm{Pl})$ and correction $(\mathrm{Cr})$.

On the basis of analysis of the test data three groups of students were also defined.

The participants of the first group showed the above average level of development of subject actions (9.7\%). They are in a minority, compared with the results of a similar group on self-actualization test. The students of this group highly estimated themselves in ability to control themselves by means of a set of subject actions, such as the analysis of arisen contradictions, forecasting, goal-setting, decision-making in a particular situation, self-control, assessment and correction of their behavior. The above average level of formation of self-control demonstrates that subjects apply a set of internal actions to harmonize them in the external world with effort of consciousness.

The second group includes students who demonstrated the ability for self-control at the average level (61\%). These students estimated self-realization of subject actions at an optimum level for a particular situation. They 
use the analysis of arisen contradictions, forecasting, goal-setting, decision-making in a particular situation, self-control, assessment and correction of their behavior, but not all the subject potential of their inner world which could manifest and show a higher level of their self-control application.

The third group was made up by participants with below average level of application of subject actions of self-control (29.3\%). This group included students with undisclosed possibilities arising in the ability to analyze internal and external contradictions, to forecast, to set a goal, to make decisions in a particular situation, to control themselves, to assess and correct themselves, as well as to use all this for self-control with various external and internal changes.

It should be noted that for the first group of students subject potential implies the availability of subject actions that one needs not only to apply but also actively use in the direction of transformation of their activities and themselves in it. This can be done with actualization and stimulation, regulation and improvement of the system of their subject actions.

As for the students of the second group of diagnostics, one must take into account the fact that it is important not only to have subject actions, but also to actualize and implement them as subject actions in relation to their inner and outer world with various changes of reality.

The third group of future professionals does not realize that it is able to be the subject of activity, therefore they need to learn, develop and implement their subject actions in relation to themselves as to the subject, object and subject of educational activity and professional practice.

On the basis of comparison of self-actualization test data with the test "The ability to control oneself", it has been revealed that the formation and implementation of subject actions of future specialists have various levels, and their subjectness has various degrees of intensity.

\section{Discussions}

It should be noted that the subject approach in Russian higher education has a widespread significance. Many lecturers use it to construct subject-subject partnerships (Meshcheryakov, 2000; Myasishchev, 1995; Klyueva, 2000 , et al.). This allows to create relevant conditions for the student's responsibility for receiving professional education.

In the course of the present empirical research, apart from the results mentioned above, we identified the indicators of manifestation of subjectness of a senior student for its assessment at a high school stage:

- Integrity (completeness) of subject manifestations in relation to the components of the inner world, object and subject of activity, since the presence of internal and external connection between all subject manifestations as well as their complementarity is provided by the functioning of a complete image "I am a subject of mastering professional competence";

- The balance of stability and flexibility (steadiness) of subject actions to various changes as resistance to external reorganizations is necessary to achieve the guaranteed results of realization of activity in it and self-realization, while flexibility is needed for successful adaptation of the subject mastering professional competence to the changing external and internal conditions, and also for their creative transformation with account for their own opportunities and perspectives of subjectness development.

The indicators of subjectness can be defined with the parameters, values, by means of which the level of formation of indicators of the specialist's subjectness is estimated. We determined and used such parameters of subject actions integrity as:

- Full implementation characterizing the completeness of mastering every subject action both in the outer and inner world of the subject of activity, and their simultaneous manifestation supplementing one other;

- Partial implementation including an imbalance in functioning of subject actions in relation to components of the inner world, the object and subject of activity, as well as a partial lack of their expression;

- Incomplete implementation, noting lack of development, unawareness, a fragmentariness of development and application of subject actions in the outer and inner world.

The balance of stability and flexibility of subject actions is determined by the following parameters:

- The steadiness of subject actions that characterizes the balance in their application in relation to external and internal changes, as with their help the specialist consciously has an opportunity, keeping the internal professionally significant contents, to modify himself for successful adaptation during their activity and creative transformation; 
- The imbalance of subject actions including a disbalance in their application in relation to the components of the inner world, the object and subject of activity with external and internal changes, as well as inability to adapt and transform them to new conditions of realization of activity and themselves in it.

It is necessary to mention that the indicators of manifestation of the student's subjectness are identified and justified in this paper for the first time.

\section{Conclusion}

It is worth noting that subjectness of a student is a professionally significant psychological formation which is reflected in the ability of the student to dispose of resources of their own inner world in the process of mastering professional competence by applying a set of subject actions in educational activity and professional practice. Self-actualization and self-control are considered the main subject actions.

Self-actualization is defined as the action providing the completeness of self-expression and a demand of manifestation of subjectness in activity of a student.

The conception of self-government is disclosed through the action providing the student with an opportunity to accompany the process of self-realization from the moment of setting an objective to its realization into the expected result through putting it forward independently, through search and implementation of solutions and means to achieve it, through analysis and assessment of the results obtained, as well as setting new purposes.

An empirical research has shown that the realization of subject actions (self-actualization and self-control) of future specialists has various levels, while their subjectness has various degrees of intensity.

\section{Conclusions}

Thus, the article discloses the conception of subjectness as a psychological formation and its manifestation through a set of subject actions of a student. Self-actualization and self-control, which ensure the quality of manifestation of the student's subjectness in the process of mastering professional competence, belong to the main subject actions. The article can be useful for high school lecturers and students seeking for self-improvement and self-development in their activity.

\section{Acknowledgments}

The work is performed according to the Russian Government Program of Competitive Growth of Kazan Federal University

\section{References}

Aksenova, G. I. (1999). Psikhologiya i pedagogika stanovleniya sub" ekta. Moscow-Ryazan : RINFO.

Ananyev, B. G. (1968). Chelovek kak predmet poznaniya. Leningrad: LGU.

Brushlinsky, A. V. (1994). Problemy psikhologii sub"'ekta. Moscow : Ins-t psikhologii RAN.

Davydov, V. V. (1996). Problemy razvivayushchegosya obucheniya. Moscow : Intor.

Eneeva, M. Yu. (1999). Psikhologicheskiye komponenty sub' 'ektnosti studenta (Extended abstract of PhD thesis). Moscow.

Klyuyeva, N. V. (2000). Tekhnologiya raboty psikhologa s uchitelem. Moscow: TC Sfera.

Kuz'mina, N. V. (1989). Professionalizm deyatel'nosti prepodavatelya i mastera proizvodstvennogo obucheniya proftekcuchilishcha. Moscow: Visshaya shkola.

Markova, A. K. (1993). Psikhologiya truda uchitelya. Moscow: Prosveshcheniye.

Maslow, A. (2009). Motivatsiya i lichnost'. SPb.: Piter.

Meshcheryakov, A. S. (2000). Teoreticheskiye osnovy proektirovaniya soderzhaniya professional'nogo obrazovaniya: metodicheskiy aspekt. Penza: PGU.

Myasishchev, V. N. (1995). Psikhologiya otnosheniy: izbr. psikhol. trudy. Moscow-Voronezh.

Osnitsky, A. K. (1996). Problemy issledovaniya sub'ektnoy aktivnosti. Voprosy psikhologii, 1, 5-19.

Petrovsky, A. V. (1990). Byt' lichnost'yu. Moscow: Pedagogika.

Petrovsky, V. A. (1993). Lichnost': fenomen sub' 'ektivnosti. Rostov.

Rubinstein, S. L. (1989). Osnovy obshchey psikhologii, 2. Moscow: Pedagogika.

Slastenin. (2000). Moscow: Magister-Press. 
Slobodchikov, V. I. (1994). Razvitiye sub"'ektivnoy realnosti v ontogeneze (Extended abstract of doctoral thesis). Moscow.

Vardanyan, Yu. V. (1998). Stanovleniye i razvitiye professional'noy kompetentsii pedagoga i psikhologa. Moscow.

Volkova, E. N. (1992). Sub'ektnost' kak integrativnoye svoystvo lichnosti pedagoga (Extended abstract of doctoral thesis). Moscow.

Yashkova, A. N. (2003). Psikhologicheskiye usloviya razvitiya spetsialista v pedagogicheskom vuze (Extended abstract of doctoral thesis). Samara.

Yashkova, A. N. (2012). Sub' 'ektnost' kak psikhologicheskaya predposylka razvitiya kar'ernoy kompetentnosti. The Humanities and Education, 2, 116-119.

Zimnyaya, I. A. (1997). Pedagogicheskaya psikhologiya. Rostov-on-Don: Feniks.

\section{Copyrights}

Copyright for this article is retained by the author(s), with first publication rights granted to the journal. This is an open-access article distributed under the terms and conditions of the Creative Commons Attribution license (http://creativecommons.org/licenses/by/3.0/). 